\title{
The Effects of Supplementation of Cinnamon and Turmeric Powder Mixture in Ration of Quail on Performance and Quality of Eggs
}

\author{
FX Suwarta ${ }^{1}$ and Ch Lilis Suryani ${ }^{2}$ \\ ${ }^{I}$ Departement of Animal Science, Faculty of Agroindustry, Mercu Buana University, Sedayu, Bantul, Yogyakarta 55753, Indonesia \\ ${ }^{2}$ Departement of Food and Agricultural Products Technology, Faculty of Agroindustry, Mercu Buana University, Yogyakarta 55753, Indonesia \\ *Corresponding author's E-mail: fxsuwarta@gmail.com; ORCID: 0000-0002-6131-0366
}

\begin{abstract}
The use of herbal ingredients to improve poultry production is increasingly developing in Indonesia. This study aimed to determine the effect of mixed supplementation of turmeric powder and cinnamon on the performance and egg quality of Japanese quail. This study consisted of four treatments with three replications ( 25 quails per replicate) established in a completely randomized design. The treatments consisted of: T0 (control); T1 (10 g turmeric $+10 \mathrm{~g}$ cinnamon) / $\mathrm{kg}$ of feed; T2 (20 g turmeric $+20 \mathrm{~g}$ cinnamon) / $\mathrm{kg}$ of feed; and T3 (40 g turmeric $+40 \mathrm{~g}$ cinnamon) $/$ $\mathrm{kg}$ of feed. Parameters measured included feed intake, body weight, feed conversion ratio, egg production, egg weight, yolk weight, yolk color index, egg white weight, eggshell weight, and egg cholesterol level. In addition, the percentage of quails reached maturity at 42 days of age were recorded. The obtained results indicated supplementation of the mixture of turmeric and cinnamon decreased feed intake and significantly improved feed conversion ratio. Quail weight at 42 days was not significantly different in different treatments. The percentage of laying quails increased in experimental treatments. Dietary supplementation with the mixture of turmeric and cinnamon significantly increased egg production, egg weight, yolk weight, yolk color index and eggshell weight. Supplementation of turmeric and cinnamon mixture significantly reduced low-density lipoprotein levels and increased high-density lipoprotein in egg yolk. It is concluded that the dietary inclusion of turmeric and cinnamon powder mixture $(40 \mathrm{~g}+40 \mathrm{~g}) / \mathrm{kg}$ of feed can improve the performance and egg quality of quails.
\end{abstract}

Key words: Cinnamon powder, Egg quality, Performance, Quail, Turmeric powder

\section{INTRODUCTION}

Quail population in Indonesia reaches 14.6 million in 2017 and produced 1.3 thousand tons of eggs (Ditjen PKH, 2018). A quail egg weighing $10 \mathrm{~g}$ contains $13 \%$ protein that is higher than protein content in a chicken egg (11\%) (Saraswati and Tana, 2016). Quail eggs contain antimicrobial nutrients, antioxidants, immuno-modulators, iron, vitamin A and B12 (Kovacs-Nolan et al., 2005). The disadvantage of quail eggs is their high cholesterol content $(16.05 \mathrm{mg} / \mathrm{g})$, which is significantly higher than chicken eggs with a content of $7.65 \mathrm{mg} / \mathrm{g}$ (Aziz et al., 2012). Herbal ingredients can be used to improve the performance of poultry because it has biological activity (Sharifi et al., 2013). Supplementation of herbal ingredients such as extracts of Artemisia, thyme, oregano, and rosemary can increase growth performance and improve feed digestibility of broiler chickens (Nosrati et al., 2017). In Broiler chickens, herbal ingredients increase antibody titers against viral diseases, especially Newcastle disease and also reduce cholesterol and triglyceride levels (Jouybari et al., 2009; Houshmand et al., 2012).

Cinnamon is an herb found in Indonesia and used as a spice in cooking. Cinnamon and its combination with other herbs are currently used as additives in poultry rations. Cinnamon contains active compounds of cinnamaldehyde and eugenol which have antiseptic, antioxidant, antimicrobial, and cholesterol-lowering effects (Tung et al., 2008; Chou et al., 2013). Cinnamon supplementation increases feed intake (Vali and Mottaghi, 2016), growth performance, and pancreatic lipase activity in broiler chickens (Kim et al, 2010). Moreover, this substance improves meat quality (Sang-oh et al., 2013), and feed intake in chickens (Isabel and Santos, 2009). Cinnamon contains proxeronine that in the body is converted to xeronine, which activates the enzymes involved in growth and improves protein absorption in the intestine (Şimşek et al., 2015). Cinnamon supplementation in quail ration can increase egg production, egg quality, and hatchability. Cinnamon and thyme supplementation in quail ration can improve egg quality, without altering the yolk weight (Vali et al., 2013).

Turmeric is a rhizome obtained from the turmeric plant (Curcuma longa). Turmeric belongs to the Zingiberacae family that is rich in phenolic compounds with anti-mutagenic and anticarcinogenic properties (Abdullah et al., 2010). Turmeric also contains active compounds such as curcumin, desmethoxycurcumin, bisdemethoxycurcumin and tetrahydro curcuminoid (Kiuch et al., 1993) with antioxidant, anti-inflammatory and nematocidal activities (Ammon et al., 1993; Kiuch et al., 1993; Osawa et al., 1995). Moreover, turmeric powder contains phytoestrogens which stimulate the 
development of ovarian follicles (Saraswati et al., 2014), therefore, supplementation of turmeric powder improves egg production and egg weight (Gumus et al., 2018).

Supplementation of turmeric in the ration can stimulate digestive enzymes and pancreatic lipase (Platel and Srinivasan, 2000). It has been reported that the addition of curcumin at a dose of $0.2 \mathrm{~g} / \mathrm{kg}$ to broiler diet increases the length and weight of duodenum, jejunum, and caeca, thereby improve the digestive process and increase the utilization of nutrients (Rajput et al., 2013). Curcumin inhibits the absorption of dietary cholesterol in the digestive tract (Arafa, 2005). It has been demonstrated that curcumin reduces levels of cholesterol and triglycerides in quail blood, also reduce LDL and increase HDL in quail eggs (Saraswati et al., 2013, 2014; Saraswati and Tana, 2016). According to all the above explanations, this study aimed to determine the effect of mixed supplementation of turmeric powder and cinnamon on the performance and egg quality of Japanese quail.

\section{MATERIALS AND METHODS}

\section{Ethical approval}

The research proceeded and conducted without hurting experimental animals under animal care rule and protocol issued by Laboratory of Animal Production Ethical Comitte, Mercu Buana University in 2019.

\section{Experimental design}

This research was carried out in Laboratory of Animal Production, Mercu Buana University, Yogyakarta Indonesia. It investigated the effects of turmeric powder (Curcuma longa) and cinnamon powder (Cinnamomum verum) on female quails (Coturnix coturnix japonica). In a completely randomized design, 300 (one-day-old) quails divided into four treatments in three replicates (Each replicate containing 25 quails). The treatments contained a mixture of turmeric and cinnamon powder (TCP) and included: T0 (control); T1 (10 g turmeric $+10 \mathrm{~g}$ cinnamon) / kg of feed; T2 (20 g turmeric $+20 \mathrm{~g}$ cinnamon) $/ \mathrm{kg}$ of feed; and T3 (40 g turmeric $+40 \mathrm{~g}$ cinnamon) $/ \mathrm{kg}$ of feed.

Turmeric root was peeled, sliced to $2 \mathrm{~mm}$ thickness and dried in an oven at $60{ }^{\circ} \mathrm{C}$ for $30-36$ hours, then grounded and sieved with a 25 -mesh sieve $(0.7 \mathrm{~mm}$ diameter $)$. Cinnamon bark was bought from a local market, cut into $2-3 \mathrm{~cm}$ sizes, dried in an oven at $60{ }^{\circ} \mathrm{C}$ for 36 hours, then grounded and sieved with a 25 -mesh sieve. One-day-old quails were adapted using commercial feed for 14 days and the experimental diets were offered at the age of 15 days. The rations were formulated iso-protein and iso-energy. The feed and drinking water were given to quails without limit (ad libitum).

The composition and nutrient content of the treatment diets are presented in table 1. Observations were made on quails between 2 to 14 weeks of age. Variables measured included feed intake, Feed Conversion Ratio (FCR), egg production, body weight at 42 days of age and percentage of laying quails at 42 days. Measurement of feed intake, body weight, FCR, and egg production was done every week, at each replication. Egg quality was determined using parameters including eggshell weight, egg weight, yolk weight, egg white weight, egg color index, cholesterol and lipoprotein levels. Egg quality measurements were carried out at the end of $6^{\text {th }}, 10^{\text {th }}$ and $14^{\text {th }}$ week, by taking three eggs randomly from each replication. Weight measurements were carried out by using a digital scale, and yolk colors were measured by comparing with an egg yolk color fan (Roches, Switzerland). Egg cholesterol levels were measured at the end of week 14, using three eggs taken randomly from each replication according to the Liebermann Burchard procedure.

Table 1. Composition and nutrient content of the treatment rations

\begin{tabular}{|c|c|c|c|c|}
\hline \multirow{2}{*}{ Feed ingredients } & \multicolumn{4}{|c|}{ Treatments } \\
\hline & T0 & T1 & T2 & T3 \\
\hline Yellow corn $(\%)$ & 50.5 & 50.5 & 50.5 & 50.5 \\
\hline Soybean meal (\%) & 25.0 & 25.0 & 25.0 & 25.0 \\
\hline Fish meal $(\%)$ & 6.0 & 6.0 & 6.0 & 6.0 \\
\hline Rice bran $(\%)$ & 16.0 & 16.0 & 16.0 & 16.0 \\
\hline Bone meal (\%) & 2.0 & 2.0 & 2.0 & 2.0 \\
\hline Premix $*(\%)$ & 0.5 & 0.5 & 0.5 & 0.5 \\
\hline Total $(\%)$ & 100.0 & 100.0 & 100.0 & 100.0 \\
\hline Turmeric powder (g/kg of feed) & 0 & 10.0 & 20.0 & 40.0 \\
\hline Cinnamon powder ( $g / \mathrm{kg}$ of feed) & 0 & 10.0 & 20.0 & 40.0 \\
\hline \multicolumn{5}{|l|}{ Nutrient content } \\
\hline Dry matter $(\%)$ & 88.40 & 88.40 & 88.40 & 88.40 \\
\hline Metabolizable energy $(\mathrm{kcal} / \mathrm{kg})$ & 2998.50 & 2998.50 & 2998.50 & 2998.50 \\
\hline Crude protein $(\%)$ & 22.18 & 22.18 & 22.18 & 22.18 \\
\hline Crude fiber $(\%)$ & 2.98 & 2.98 & 2.98 & 2.98 \\
\hline Calcium $(\%)$ & 0.94 & 0.94 & 0.94 & 0.94 \\
\hline Available phosphorus (\%) & 0.86 & 0.86 & 0.86 & 0.86 \\
\hline
\end{tabular}

To cite this paper: Suwarta FX and Suryani ChL (2019). The Effects of Supplementation of Cinnamon and Turmeric Powder Mixture in Ration of Quail on Performance an 


\section{Statistical analysis}

The collected data were analyzed by analysis of variance followed by Duncan's multiple range test using SPSS software version 17 . A p-value $<0.05$ was considered statistically significant.

\section{RESULTS}

The results of supplementation various levels of TCP on feed intake, body weight, the percentage of laying quails at 42 days, egg quality, cholesterol and lipoprotein levels in eggs are presented in table 2. The highest TCP inclusion level (T3) reduced feed intake significantly compared to T0 and T1 $(\mathrm{p}<0.05)$. There was no significant difference in body weight between the control and TCP supplemented diets. The increase in TCP level significantly increased egg production, yolk weight, egg white weight, eggshell weight, and yolk color index compared to the control group ( $\mathrm{p}<0.05)$. The birds on T3 had the highest number of laying quails $(28.33 \%)$ compared to T0 and T1 $(11.67 \%)$. The highest egg production was recorded in birds on T3 that was significantly different compared to the T0 and T1. The TCP supplementation significantly improved FCR and increased egg weight. The highest TCP inclusion level significantly reduced cholesterol and LDL and increased egg yolk HDL compared to other treatments $(\mathrm{p}<0.05)$.

Table 2. The Effects of turmeric powder and cinnamon powder mixture on quail performance and egg quality

\begin{tabular}{lcccc}
\hline \multirow{2}{*}{ Variables } & \multicolumn{3}{c}{ Treatments } \\
\cline { 2 - 5 } & T0 & T1 & T2 & T3 \\
\hline Feed intake (g/bird/day) & $20.43 \pm 0.15^{\mathrm{a}^{\mathrm{a}}}$ & $20.13 \pm 0.58^{\mathrm{ab}}$ & $19.90 \pm 0.40^{\mathrm{bc}}$ & $19.53 \pm 0.12^{\mathrm{c}}$ \\
Body weight at 42 days of age (g) & $195.7 \pm 3.38^{\mathrm{a}}$ & $187.1 \pm 6.64^{\mathrm{a}}$ & $186.7 \pm 5.03^{\mathrm{a}}$ & $185.9 \pm 11.23^{\mathrm{a}}$ \\
Percentage of laying quail at 42 days & $11.67 \pm 2.88^{\mathrm{a}}$ & $20.00 \pm 500^{\mathrm{b}}$ & $23.33 \pm 2.88^{\mathrm{bc}}$ & $28.33 \pm 2.88^{\mathrm{c}}$ \\
Hen day average (\%) & $68.03 \pm 0.47^{\mathrm{a}}$ & $71.88 \pm 0.93^{\mathrm{b}}$ & $71.52 \pm 0.62^{\mathrm{bc}}$ & $70.28 \pm 0.86^{\mathrm{cd}}$ \\
Feed conversion ratio & $3.39 \pm 0.47^{\mathrm{a}}$ & $3.06 \pm 0.93^{\mathrm{a}}$ & $3.11 \pm 0.62^{\mathrm{b}}$ & $3.12 \pm 0.09^{\mathrm{b}}$ \\
Egg weight (g/egg) & $9.3 \pm 0.19^{\mathrm{a}}$ & $10.54 \pm 0.12^{\mathrm{b}}$ & $10.25 \pm 0.17^{\mathrm{ab}}$ & $10.46 \pm 0.41^{\mathrm{c}}$ \\
Yolk weight (g/egg) & $2.92 \pm 0.19^{\mathrm{a}}$ & $3.36 \pm 0.05^{\mathrm{b}}$ & $3.29 \pm 0.16^{\mathrm{b}}$ & $3.42 \pm 0.12^{\mathrm{c}}$ \\
Egg white weight (g/egg) & $5.25 \pm 0.13^{\mathrm{a}}$ & $6.24 \pm 0.18^{\mathrm{b}}$ & $6.01 \pm 0.14^{\mathrm{bc}}$ & $5.94 \pm 0.23^{\mathrm{bc}}$ \\
Eggshell weight (g/egg) & $0.98 \pm 0.03^{\mathrm{a}}$ & $1.03 \pm 0.02^{\mathrm{ab}}$ & $1.00 \pm 0.04^{\mathrm{ab}}$ & $1.03 \pm 0.04^{\mathrm{b}}$ \\
Egg yolk color index & $3.31 \pm 0.10^{\mathrm{a}}$ & $3.99 \pm 0.16^{\mathrm{b}}$ & $4.68 \pm 0.12^{\mathrm{c}}$ & $5.45 \pm 0.17^{\mathrm{d}}$ \\
Egg yolk cholesterol (mg/100 g) & $1303.0 \pm 17.5^{\mathrm{a}}$ & $1300.7 \pm 33.6^{\mathrm{b}}$ & $1222 . \pm 18.3^{\mathrm{c}}$ & $1134.8 \pm 19.0^{\mathrm{d}}$ \\
HDL (mg/100 mg) & $113.36 \pm 0.51^{\mathrm{a}}$ & $116.50 \pm 2.0^{\mathrm{a}}$ & $125.62 \pm 1.00^{\mathrm{b}}$ & $121.85 \pm 8.10^{\mathrm{c}}$ \\
LDL (mg/100 mg) & $145.93 \pm 0.55^{\mathrm{a}}$ & $140.67 \pm 0.96^{\mathrm{b}}$ & $134.67 \pm 0.47^{\mathrm{c}}$ & $130.47 \pm 6.20^{\mathrm{d}}$ \\
\hline
\end{tabular}

* Mean \pm Standard Deviation, T0 (control); T1: (10 g turmeric + $10 \mathrm{~g}$ cinnamon) / kg of feed; T2: $(20 \mathrm{~g}$ turmeric $+20 \mathrm{~g}$ cinnamon) / kg of feed; T3: (40 $\mathrm{g}$ turmeric $+40 \mathrm{~g}$ cinnamon) $/ \mathrm{kg}$ of feed. Different superscripts letters within the same row indicate statistically different ( $\mathrm{p}<0.05)$.

\section{DISCUSSION}

An increase in TCP supplementation resulted in reduced feed intake that is due to changes in the aroma, palatability, and taste of the feed. Rahardja et al. (2016) stated the supplementation of turmeric powder ranged from $0.1,2$ and $4 \%$ in the ration reduced the feed intake in Hisex Brown laying hens from the age of 80 to 92 weeks. Malekizadeh et al. (2012) reported that rations supplemented with turmeric powder (1-3\%) decreased feed intake in laying chicken at 103 to 112 weeks old. Riasi et al. (2012) stated that dietary inclusion of turmeric at levels of 0.15 and $0.20 \%$ reduced feed intake. However, cinnamon supplementation at a level of $12.0 \mathrm{~g} / \mathrm{kg}$ of diet did not affect quail feed intake, as the consumption of feed is determined by energy and protein levels (Santos et al., 2019). A study conducted by Hassan (2016) revealed that the use of cinnamon and rosemary oil mixtures in the quail diet did not affect feed intake.

Although TCP supplementation reduced feed intake, it did not affect body weight. This finding indicated that TCP can improve feed utilization efficiency and growth. Turmeric increases the excretion of digestive enzymes, pancreatic lipase (Platel and Srinivasan, 2000) and intestine villi size, thus improve nutrient absorption in birds (Rajput et al., 2013). It was found that supplementation of a mixture of turmeric and cumin at $5.0 \mathrm{~g} / \mathrm{kg}$ of feed can increase body weight (ALKassie, 2011). The use of turmeric powder at a level of $1.0 \mathrm{~g} / \mathrm{kg}$ of feed improved growth performance in broiler chickens (Kumari et al., 2007). However, Emadi and Kermanshahi (2006) reported that the administration of turmeric powder $(0.25 \% .0 .5 \%$. and $0.75 \%)$ did not affect feed intake, body weight, and FCR in broilers. The use of cinnamon powder and Gotu kola as a feed additive increased the digestibility and absorption of nutrients, thus improved body weight in broiler chickens. The number of quails that reach adulthood at T3 $(28.33 \%)$ was significantly higher than that in T0 (11.67\%). Turmeric and cinnamon contain phytoestrogen which affects the reproduction of poultry. In addition, phytoestrogens induce vitellogenin synthesis in hepatocytes, resulting in increasing the vitellogenin deposition in egg yolk (Levi et al., 2009). Vitellogenin is transported through the bloodstream to the ovaries thereby increasing follicle

To cite this paper: Suwarta FX and Suryani ChL (2019). The Effects of Supplementation of Cinnamon and Turmeric Powder Mixture in Ration of Quail on Performance an 
growth (Elnagar and Abd-Elhady, 2009). Minerals in cinnamon have a positive effect on reproductive performance and egg production of laying poultry (Namra et al., 2008). Cinnamon supplementation can increase zinc levels in blood serum (Şimşek et al., 2015) and zinc has a strong antioxidant activity thereby protecting the oxidative damage of membrane cells (Sahin and Kucuk, 2003). Turmeric powder supplementation with a dose of $108 \mathrm{mg} /$ quail/day resulted in $75 \%$ of quails started laying at 42 days, while in the control group that did not receive turmeric powder supplementation, $42.86 \%$ of quails started laying at 44 days (Saraswati and Tana, 2016). In addition, Saraswati et al. (2013) reported that quails fed a non-supplemented diet with turmeric powder, reproductive maturity was delayed and the quails started laying at the age of 45 days.

TCP supplementation significantly improved egg production, egg weight, and FCR due to the positive effects of turmeric and cinnamon on improving intestinal absorption. The use of cinnamon and thyme can increase the length of the intestine as well as depth and width of villi, therefore, improve nutrient absorption and ultimately increase egg production and egg quality (Şimşek et al., 2015). Supplementation of turmeric powder at a level of $0.5 \%$ increased egg production and egg weight in laying hens (Radwan et al., 2008). Vali et al. (2013) stated that cinnamon and thyme treatment could significantly improve quail egg quality, except yolk weight. Supplementation of turmeric powder up to $4 \%$ in chicken rations increased the body weight, feed intake, and egg production. The use of $2 \%$ turmeric powder compared to $4 \%$ led to a better FCR and lighter-colored yolks. In addition, diet supplemented with $2 \%$ turmeric powder significantly increased chicken egg weight compared to control diet. However, the use of turmeric $4 \%$ resulted in lower egg weight compared to the control diet (Ali et al., 2007). Riasi et al. (2012) stated that the addition of $0.2 \%$ turmeric powder to laying hens (100-104 week-old) significantly increased the egg weight and improved FCR. Durrani et al. (2006) reported that diet supplemented with turmeric ( $5 \mathrm{~g} / \mathrm{kg}$ of diet) resulted in a significant improvement in body weight gain and FCR. Park et al. (2012) found that the addition of $0.01,0.25$, and $0.5 \%$ turmeric powder in diet of Lohmann Brown laying hens (60 to 67-week-old) significantly increased egg production.

Egg cholesterol level was improved in diets supplemented with TCP. This finding can be attributed to the effect of turmeric on improving nutrient absorption (Saraswati and Tana, 2016). Curcumin inhibits the absorption of cholesterol in the feed (Arafa, 2005) and is an antiatherogenic compound (Emadi and Kermanshahi, 2006) which decreases blood cholesterol levels and amount of cholesterol transferred to the yolk. Also, cinnamon has cholesterol-lowering activity. Diet supplementation with thyme and cinnamon powder at levels of $1 \%$ and $2 \%$ increased unsaturated fatty acids and reduced saturated fatty acids in quail eggs (Vali and Mottaghi, 2016). The use of a combination of turmeric and thyme powder reduced LDL and HDL because antioxidants from plants can control hormones, inhibit lipase activity, increase protein deposition and reduce fat deposition (Fallah and Mirzaei, 2016). Curcumin increases LDL receptors which play a role in lowering blood LDL levels (Peschel et al., 2007). Curcumin also decreases the LDL/HDL ratio (Qinna et al., 2012).

\section{CONCLUSION}

Based on the results obtained in the current study, it was demonstrated that supplementation of turmeric and cinnamon mixture in quail rations could improve the growth performance, egg production, and egg quality. Also, turmeric and cinnamon also significantly reduced levels of low-density lipoproteins and increased high-density lipoproteins in quail egg yolks.

\section{DECLARATIONS}

\section{Acknowledgments}

The authors thank to the Directorate of Higher Education, the Ministry of Research and Technology of Indonesia for the research grant.

\section{Authors' contributions}

FX Suwarta was responsible for research design, data collection, data analysis, and manuscript writing. Ch Lilis Suryani was responsible for laboratory analysis, interpretation of data, and manuscript revision. All authors read and approved the manuscript.

\section{Competing interests}

The authors declared that no competing interest exists.

\section{REFERENCES}

Abdullah S, Abidin SAZ, Murad NA, Makpol S, Ngah WZW and Yusof YAM (2010). Ginger extract (Zingiber officinale) triggers apoptosis and G0/G1 cells arrest in HCT 116 and HT 29 colon cancer cell lines. African Journal of Biochemistry Research, 4(5): 
Ali MN, Hassan MS and El-Ghany FA (2007). Effect of strain, type of natural antioxidant and sulphate ion on productive, physiological and hatching performance of native laying hens. International Journal of Poultry Science, 6(8): 539-554. Available at: http://docsdrive.com/pdfs/ansinet/ijps/2007/539-554.pdf

AL-Kassie GA, Mohseen AM and Abd-AL-Jaleel RA (2011). Modification of productive performance and physiological aspects of broilers on the addition of a mixture of cumin and turmeric to the diet. Research Opinions in Animal and Veterinary Sciences. 1(1): 31-34. Available at: http://agris.fao.org/agris-search/search.do?recordID=DJ2012071824

Ammon HPT, Safayhi H, Mack T and Sabieraj J (1993). Mechanism of anti-inflammatory actions of curcumin and boswellic acids. Journal of Ethnopharmacology, 38(2-3): 105-112. DOI: https://doi.org/10.1016/0378-8741(93)90005-P

Arafa HM (2005). Curcumin attenuates diet-induced hypercholesterolemia in rats. Medical Science Monitor, 11(7): 228-234. Available at: https://www.medscimonit.com/abstract/index/idArt/16975/new/1/act/3

Aziz Z, Cyriac S, Beena V and Philomina PT (2012). Comparison of cholesterol content in chicken, duck and quail eggs. Journal of Veterinary Animal Science, 43: 64-66. Available at: www.cvaslibrary.com/journals/1_43_15.pdf

Chou ST, Chang WL, Chang CT, Hsu SL, Lin YC and Shih Y (2013). Cinnamomum cassia essential oil inhibits $\alpha$-MSH-induced melanin production and oxidative stress in murine B16 melanoma cells. International Journal of Molecular Sciences, 14(9): 19186-19201. DOI: https://doi.org/10.3390/ijms140919186

Ditjen PKH (2018). Statistik Peternakan dan Kesehatan Hewan 2018 / Livestock and Animal Health Statistics 2018. Available at: http://ditjenpkh.pertanian.go.id/buku-statistik-peternakan-dan-kesehatan-hewan-tahun-2018

Durrani FR, Ismail M, Sultan A, Suhail SM, Chand N and Durrani Z (2006). Effect of different levels of feed added turmeric (Curcuma longa) on the performance of broiler chicks. Journal of Agricultural and Biological Science, 1(2): 9-11. Available at: http://agris.fao.org/agris-search/search.do?recordID=US201300882543

Elnagar SA and Abd-Elhady AM (2009). Exogenous estradiol: productive and reproductive performance and physiological profile of Japanese quail hens. International Journal of Poultry Science, 8(7): 634-641. DOI: https://doi.org/10.3923/ijps.2009.634.641

Emadi M and Kermanshahi H (2006). Effect of turmeric rhizome powder on performance and carcass characteristics of broiler chickens. International Journal of Poultry Science, 5(11): 1069-1072. DOI: https://doi.org/10.3923/ijps.2006.1069.1072

Fallah R and Mirzaei E (2016). Effect of dietary inclusion of turmeric and thyme powders on performance, blood parameters and immune system of broiler chickens. Livest. Sci, 7(1): 180-186. Available at: http://livestockscience.in/wpcontent/uploads/turmeric-thym-brolier-iran.pdf

Gumus H, Oguz MN, Bugdayci KE and Oguz FK (2018). Effects of sumac and turmeric as feed additives on performance, egg quality traits, and blood parameters of laying hens. Revista Brasileira de Zootecnia, 47. DOI: https://doi.org/10.1590/rbz4720170114

Hassan SM (2016). Effects of adding different dietary levels of Turmeric (Curcuma longa Linn) powder on productive performance and egg quality of laying hens. International Journal of Poultry Science, 15(4): 156-60. DOI: https://doi.org/10.3923/ijps.2016.156.160

Houshmand M, Azhar K, Zulkifli I, Bejo MH and Kamyab A (2012). Effects of non-antibiotic feed additives on performance, immunity and intestinal morphology of broilers fed different levels of protein. South African Journal of Animal Science, 42(1): 23-32. DOI: https://doi.org/10.4314/sajas.v42i1.3

Isabel B and Santos Y (2009). Effects of dietary organic acids and essential oils on growth performance and carcass characteristics of broiler chickens. Journal of Applied Poultry Research. 18(3): 472-476. DOI: https://doi.org/10.3382/japr.2008-00096

Jouybari MG, Pour VR, Nagharchi MMZ, Taghizadeh MR and Dehpanah N (2009). The effect of novel probiotic on blood parameters and performance in broiler chickens. Journal of Cell and Animal Biology, 3(8): 141-144. Available at: www.academicjournals.org/app/webroot/article/article1380203259_Jouybari\%20et\%20al.pdf

Kim DK, Lillehoj HS, Lee SH, Jang SI and Bravo D (2010). High-throughput gene expression analysis of intestinal intraepithelial lymphocytes after oral feeding of carvacrol, cinnamaldehyde, or Capsicum oleoresin. Poultry Science, 89(1): 68-81. DOI: https://doi.org/10.3382/ps.2009-00275

Kiuch F, Goto Y, Sugimoto N, Tsuda Y, Akao N and Kondo K (1993). Nematocidal activity of turmeric: synergistic action of curcuminoids. Chemical and Pharmaceutical Bulletin, 41(9): 1640-1643. DOI: https://doi.org/10.1248/cpb.41.1640

Kovacs-Nolan J, Phillips M and Mine Y (2005). Advances in the value of eggs and egg components for human health. Journal of Agricultural and Food Chemistry, 53(22): 8421-8431. DOI: https://doi.org/10.1021/jf050964f

Kumari P, Gupta MK, Ranjan R, Singh KK and Yadava R (2007). Curcuma longa as feed additive in broiler birds and its pathophysiological effects. Indian Journal of Experimental Biology, 45(3): 272-277. Available at: http://nopr.niscair.res.in/handle/123456789/5246

Levi L, Pekarski I, Gutman E, Fortina P, Hyslop T, Biran J, Levavi-Sivan B and Lubzens E (2009). Revealing genes associated with vitellogenesis in the liver of the zebrafish (Danio rerio) by transcriptome profiling. BMC genomics, 10(1): 141. DOI: https://doi.org/10.1186/1471-2164-10-141

Malekizadeh M, Moeini MM and Ghazi S (2012). The effects of different levels of ginger (Zingiber officinale Rosc) and turmeric (Curcuma longa Linn) rhizomes powder on some blood metabolites and production performance characteristics of laying hens. Journal of Agricultural Science and Technology, 14: 127-134. Available at: http://jhs.modares.ac.ir/article-23-4117-en.pdf

Namra MMM, Wahed HMA and Fayek HM (2009). Evaluation of different sources of dietary zinc supplementation for Japanese quail: 2-Laying performance. Egyptian Poultry Science Association, 29: 127-143. Available at: https://pdfs.semanticscholar.org/2654/160e3bccc03d084a37cc18787d13e60ebccc.pdf

Nosrati M, Javandel F, Camacho LM, Khusro A, Cipriano M, Seidavi A and Salem AZM (2017). The effects of antibiotic, probiotic, organic acid, vitamin $\mathrm{C}$, and Echinacea purpurea extract on performance, carcass characteristics, blood chemistry, microbiota, 
and immunity of broiler chickens. Journal of Applied Poultry Research, 26(2): 295-306. DOI: https://doi.org/10.3382/japr/pfw073

Osawa T, Sugiyama Y, Inayoshi M and Kawakishi S (1995). Antioxidative activity of tetra hydro curcuminoids. Bioscience, biotechnology, and biochemistry, 59(9): 1609-1612. DOI: https://doi.org/10.1271/bbb.59.1609

Park SS, Kim JM, Kim EJ, Kim HS, An BK and Kang CW (2012). Effects of dietary turmeric powder on laying performance and egg qualities in laying hens. Korean Journal of Poultry Science, 39(1): 27-32. DOI: https://doi.org/10.5536/kjps.2012.39.1.027

Peschel D, Koerting R and Nass N (2007). Curcumin induces changes in expression of genes involved in cholesterol homeostasis. The Journal of nutritional biochemistry, 18(2): 113-119. DOI: https://doi.org/10.1016/j.jnutbio.2006.03.007

Platel K and Srinivasan K (2000). Influence of dietary spices and their active principles on pancreatic digestive enzymes in albino rats. Food/Nahrung, 44(1): 42-46. DOI: https://doi.org/10.1002/(SICI)1521-3803(20000101)44:1<42::AID-FOOD42>3.0.CO;2D

Qinna NA, Kamona BS, Alhussainy TM, Taha H, Badwan AA and Matalka KZ (2012). Effects of prickly pear dried leaves, artichoke leaves, turmeric and garlic extracts, and their combinations on preventing dyslipidemia in rats. ISRN Pharmacology, 2012. DOI: https://doi.org/10.5402/2012/167979

Radwan Nadia L, Hassan RA, Qota EM and Fayek HM (2008). Effect of natural antioxidant on oxidative stability of eggs and productive and reproductive performance of laying hens. International Journal of Poultry Science, 7(2): 134-150. Available at: www.docsdrive.com/pdfs/ansinet/ijps/2008/134-150.pdf

Rahardja DP, Hakim MR and Lestari VS (2015). Egg production performance of old laying hen fed dietary turmeric powder. International Journal of Animal and Veterinary Sciences, 2(7): 264 Available at: https://pdfs.semanticscholar.org/4ae8/8c660359a3a40b68fba44b75f3fda9ca6054.pdf

Rajput N, Muhammad N, Yan R, Zhong X and Wang T (2013). Effect of dietary supplementation of curcumin on growth performance, intestinal morphology and nutrients utilization of broiler chicks. The Journal of Poultry Science, 50(1): 44-52. DOI: https://doi.org/10.2141/jpsa.0120065

Riasi A, Kermanshahi H and Mahdavi AH (2012). Production performance, egg quality and some serum metabolites of older commercial laying hens fed different levels of turmeric rhizome (Curcuma longa) powder. Journal of Medicinal Plants Research, 6(11): 2141-2145. Available at: https://riasi.iut.ac.ir/sites/riasi.iut.ac.ir/files/file_pubwdet/riasi2.pdf

Sahin K and Kucuk O (2003). Zinc supplementation alleviates heat stress in laying Japanese quail. The Journal of nutrition, 133(9): 2808-2811. DOI: https://doi.org/10.1093/jn/133.9.2808

Sang-Oh P, Chae-Min R, Byung-Sung P and Jong H (2013). The meat quality and growth performance in broiler chickens fed diet with cinnamon powder. Journal of Environmental Biology, 34(1): 127. Available at: https://www.cabdirect.org/cabdirect/abstract/20133219692

Santos TS, Lopes CDC, Junior O, Murilo G, Santos LM, Santana CCS and Souza DM (2019). The use of cinnamon powder in the diet of Japanese laying quail. Acta Scientiarum. Animal Sciences, 41: 1-7. DOI: https://doi.org/10.4025/actascianimsci.v41i1.42963

Saraswati TR and Tana S (2016). Effect of Turmeric Powder Supplementation to The Age of Sexual Maturity, Physical, and Chemical Quality of The First Japanese Quail's (Coturnix japonica) Egg. Biosaintifika Journal of Biology and Biology Education, 8: 18-24. DOI: https://doi.org/10.15294/biosaintifika.v8i1.4982

Saraswati TR, Manalu W, Ekastuti DR and Kusumorini N (2013). The role of turmeric powder in lipid metabolism and its effect on quality of the first quail's egg. Journal of The Indonesian Tropical Animal Agriculture, 38(2): 123-130. DOI: https://doi.org/10.14710/jitaa.38.2.123-130

Saraswati TR, Manalu W, Ekastuti DR and Kusumorini N (2014). Effect of turmeric powder to estriol and progesterone hormone profile of laying hens during one cycle of ovulation. International Journal of Poultry Science, 13(9): 504-509. DOI: https://doi.org/10.3923/ijps.2014.504.509

Sharifi SD, Khorsandi SH, Khadem AA, Salehi A and Moslehi H (2013). The effect of four medicinal plants on the performance, blood biochemical traits and ileal microflora of broiler chicks. Veterinarski arhiv, 83(1): 69-80. Available at: wwwstaro.vef.unizg.hr/vetarhiv/papers/2013-83-1-8.pdf

Şimşek ÜG, Ciftci M, Özçelik M, Azman MA, Tonbak F and Özhan N (2015). Effects of cinnamon and rosemary oils on egg production, egg quality, hatchability traits and blood serum mineral contents in laying quails (Coturnix coturnix Japonica). Ankara Üniv Vet Fak Derg, 62, 229-236. DOI: https://doi.org/10.1501/vetfak_0000002685

Tung YT, Chua MT, Wang SY and Chang ST (2008). Anti-inflammation activities of essential oil and its constituents from indigenous cinnamon (Cinnamomum osmophloeum) twigs. Bioresource Technology, 99(9): 3908-3913. DOI: https://doi.org/10.1016/j.biortech.2007.07.050

Vali N and Mottaghi S (2016). The effect of using different levels of cinnamon and thyme powder on egg characteristics and fatty acids profile in Japanesese quail. CIBTech Journal of Zoology, 5(3): 2319-3883. Available at: https://pdfs.semanticscholar.org/84ae/d7be83432705551a9a09e8fcf0a51f7e4080.pdf

Vali N, Shahin H and Vatankhah M (2013). Determination of the effects of Cinnamomum zeylanicum Blume and Thymus vulgaris on performance and egg quality of Japanese quail (Coturnix japonica). Research Opinions in Animal and Veterinary Sciences, 3(9): 280-284. Available at: www.roavs.com/pdf-files/Issue-9-2013/280-284.pdf 